\title{
DLACZEGO EUKLIDES BYŁ OSŁEM? UWAGI O JEDNE] Z POWIEŚCI STEFANA THEMERSONA
}

\section{JACEK KWOSEK}

\section{WHY WAS EUCLID A DONKEY? REMARKS ON STEFAN THEMERSON'S THE MYSTERY OF THE SARDINE}

\begin{abstract}
The article concerns the Stefan Themerson's novel The mystery of the sardine (polish title: Euklides był osłem). First, it discusses the philosophical inspirations inherent in the novel. Then a critique of the mental tendencies in Western philosophy symbolized by Euclid is presented. Themerson criticizes the assumption, that eternal and immutable things are the basis of mutable and temporal things. He also rejects the view, that a priori knowledge about the real world is possible. Instead, he proclaims the primacy of factual truths over those of reason, and the primacy of experience over abstract inferences. He also argues that assigning too much of a priori cognition leads to the creation of world repair projects, which justify fanaticism and cruelty. Instead, he proposes an ethics of good manners resp. rules of decency.
\end{abstract}

KEY WORDS Themerson Stefan, philosophy, Euclid, The mystery of the sardine CONTACT Uniwersytet Śląski w Katowicach;jacek.kwosek@us.edu.pl 
Niniejsza praca ma stanowić komentarz filozoficzny do powieści Stefana Themersona Euklides był osłem. (Themerson 2013). ${ }^{1}$ Tytuł pochodzi z rozprawy Iana - jednego z bohaterów powieści w której została przedstawiona geometria alternatywna w stosunku do geometrii Euklidesa. Zgodnie z geometrią postulowaną przez Iana czas i przestrzeń nie są ciągłe, lecz ziarniste, co oznacza, że istnieją najmniejsze porcje czasu i przestrzeni. Zamierzamy wskazać niektóre filozoficzne źródła tej idei i odpowiedzieć na pytanie postawione w tytule. Wydaje się jasne, że Euklides dla Themersona stanowi symbol postawy myślowej, wobec której zajmuje postawę polemiczną. Celem naszym jest więc jej opis oraz przedstawienie alternatywy proponowanej przez Themersona, głównie w oparciu o tekst jego powieści.

Swój zamysł teoretyczny Ian przedstawia tak: „Celem tej pracy jest wykazanie, że Euklides był osłem. Był przekonany, że to, co słuszne dla trójkąta wielkości jego nosa i dla koła wielkości jego tyłka, będzie słuszne dla wszystkich trójkątów i kół, niezależnie od tego, jak ogromnych, czy jak malutkich. Był tak pewien tego, że nawet nie zadał sobie trudu, by zapisać to jako jeden ze swoich postulatów [...]" (Themerson 2013: 229). I dalej:

„Moje założenia są następujące:

Istnieje najmniejsza cząsteczka Przestrzeni. Będę ją nazywał Emmą.

Istnieje najmniejsza cząsteczka Czasu. Będę ją nazywał Janem." (s. 229)

Emma to imię ukochanej Iana. Następnie Ian objaśnia, że zarówno Emma, jak i Ian są niepodzielne, a zatem $\mathrm{w}$ wyniku próby ich podzielenia powstałoby coś, co nie posiada własności Przestrzeni, ani Czasu. (Themerson 2013: 220-230). Zauważmy przy okazji, że w taki sam sposób niepodzielne są wszelkie przedmioty indywidualne, np. człowiek albo tygrys. „Gdyż połowa tygrysa to już nie jest tygrys.” (Themerson 2013: 234). Emma nie jest punktem: ma długość, szerokość i grubość, ale nie ma kształtu, „bo żeby mieć kształt, musiałaby mieć jakieś części, a jej części (jeśli jakieś ma) nie należą do świata Przestrzeni. Nie ma stałego położenia, ponieważ istnieje tylko w czasie jednego Iana, to znaczy: jednego Iana po drugim, a między nimi nic." (Themerson 2013: 230). Wobec tego linia nie jest też linią w rozumieniu Euklidesa: posiada grubość jednej Emmy i składa się z co najwyżej przeliczalnej ilości Emm. ${ }^{2}$ Jego linię można podzielić na dwie połowy tylko wtedy, gdy składa się z parzystej liczby Emm. „Na tym to polega. Pitagorasowi by się to spodobało, jestem pewien." (Themerson 2013:231). ${ }^{3}$

Skoro w matematyce tworzonej przez Iana istnieją najmniejsze cząstki czasu i przestrzeni, nie mogą w niej istnieć doskonały kwadrat i doskonałe koło, ponieważ do wyrażenia długości przekątnej kwadratu potrzebny jest pierwiastek kwadratowy z 2, zaś do wyrażenia obwodu koła potrzebna jest liczba pi. O pojęciu koła u Euklidesa Ian pisze nader nieuprzejmie: „Moje koło nie jest, jak jego tyłek. Moje koło nie potrzebuje pośrodku dziury w dupie. Możesz nakreślić moje koło krok po kroku, idąc krok po kroku z jedną nogą nieco krótszą niż druga." (Themerson 2013: 231). Wynika stąd, że koło jest wielobokiem, w którym każdy jego bok ma wielkość jednej Emmy: „Tak więc najmniejsze koło jest trójkątem z trzech Emm, a drugie z ko-

3 Dla pitagorejczyków, jak i dla Greków w ogóle, liczba była proporcją. Dlatego odkrycie liczb niewymiernych, tj. nie dających się wyrazić w postaci ułamka spowodowało szok. Na temat pitagorejczyków por. Legutko 2020: 118-143. 
lei koło jest kwadratem z czterech Emm i tak dalej, a koło wielkości tyłka Euklidesa składa się z milionów milionów Emm [...] W moim kole, kiedy dziesiętna pi zmniejsza się do rozmiarów jednej Emmy, głupią bzdurą jest ciągną́ to dalej." (Themerson 2013: 231).

Trzeba podkreślić, że Ian swą geometrię uznaje za opis realnego świata, a nie za jedną z możliwych konstrukcji matematycznych. Stwierdza, że gdy Bóg stworzył Emmę, uznał ją za coś absolutnie doskonałego. „Potem ten głupi osioł Euklides obwieścił, że doskonałe są tylko jego, Euklidesa, koła i kwadraty. Więc Bóg także spróbował stworzyć doskonałe koła i kwadraty ze swoich Emm, ale nie mógł." (Themerson 2013: 233). We wszechświecie z ziarnistą, nieciągłą przestrzenią, kwadraty i koła są po prostu niemożliwe i nawet Bóg nie może tego zmienić. ${ }^{4}$ Figury te muszą stale wibrować, przybliżając się jedynie do kwadratu/koła, zatem podstawą wszechrzeczy są ruch i zmiana. Czas i materia są właśnie skutkiem tych wibracji. Nieskończenie podzielne mogą być jedynie przedmioty fikcyjne. (Themerson 2013: 233-235). Na koniec Ian wyraża nadzieję, że uda mu się wykazać, że postulowane przez fizykę cząstki elementarne są w istocie „rozlicznymi kombinacjami rozlicznych drgań, wszystkich opartych na podstawowej częstotliwości Emma/Jan.” (Themerson 2013: 235). Jego geometria jest więc jednocześnie programem badania świata, opartym na zupełnie innych zasadach, niż te postulowane przez Euklidesa.

Nietrudno zauważyć, że mamy tu do czynienia z nawiązaniem do Platona, a zarazem odwróceniem jego założeń. Dla Platona świat zmysłowy jest niedoskonałym odzwierciedleniem świata wiecznych i niezmiennych idei, stanowiących prawzorce wszystkich rzeczy. Byty konkretne są zmienne i tylko partycypują w ideach, tj. częściowo realizują ich treści. ${ }^{5}$ By wyjaśnić zachodzenie związku między światem idei i światem zmysłowym, Platon pisze w Timajosie o Demiurgu, który z nieuformowanej materii stwarza byty konkretne na wzór idei. Świat stworzony przez Demiurga jest najdoskonalszy z możliwych, tj. zawierający jak najwięcej współmożliwych bytów (tzw. zasada pełności), ${ }^{6}$ jednak mimo to nie jest doskonały z uwagi na swą zmienność. Czas jest niedoskonałym odzwierciedleniem wieczności i dlatego musi być cykliczny - skoro byty konkretne są zmienne, to przynajmniej muszą się cyklicznie pojawiać, by jak najlepiej upodobnić się do tego, co wieczne. (Platon 1986: 35-53).7 Themerson przyjmuje, że zmienność jest wpisana w naturę naszego świata, lecz w odróżnieniu od Platona nie uważa jej za oznakę niedoskonałości. Co więcej, w jego ujęciu to właśnie byty konkretne, zdają się być bardziej realne od abstraktów. Geometria Iana jest lepsza niż geometria Euklidesa, ponieważ opisuje świat realny, z jego zmiennością, gdy Euklides zajmuje się bytami fikcyjnymi - jego koło i kwadrat mają ten sam status, co jednorożce i postaci literackie. W pewnym jednak sensie nasz świat jest rezultatem Bożego błędu - przypomnijmy, że Bóg stwarza Emmę jako doskonałą i dopiero pod wpływem Euklidesa (!) próbuje stwarzać idealne koła i kwadraty, co Mu się nie udaje. Dzięki temu jednak w świecie pojawia się czas. Opowieść Iana o Bogu usiłującym, wbrew

$4 \quad$ Musiałby stworzyć świat całkiem inaczej, według pomysłów Euklidesa. Jednak skoro już stworzył świat, w którym czas i przestrzeń nie są nieskończenie podzielne, to sam Jego zamysł stwórczy ogranicza Jego wszechmoc (potentia Dei ordinata).

$5 \quad$ Por. łacińskie partem capere - brać część.

6 Zasada pełności głosi, że cokolwiek jest możliwe, jest konieczne. Na temat jej źródeł i jej znaczenia w myśli Zachodu por. Lovejoy 2009.

7 Paginacja boczna $28 \mathrm{c}-42 \mathrm{e}$ 
swemu pierwotnemu zamysłowi, ufundować świat zmysłowy na tym, co niezmienne, stanowi replikę platońskiego mitu o Demiurgu tworzącym świat na wzór wiecznych i niezmiennych idei.

Przyznanie obiektom postulowanym przez geometrię Euklidesa statusu bytów fikcyjnych uderza w pogląd, który Davis, Hersh i Marchisotto nazywają mitem Euklidesowym. „Jest to przekonanie, że książki Euklidesa zawierają prawdę o wszechświecie, jasną i niepodważalną. Zaczynając od oczywistych prawd i postępując drogą rygorystycznego dowodzenia, dochodził Euklides do wiedzy, która jest pewna, obiektywna i wieczna." (Davis, Hersh i Marchisotto: 315). Był on łączony z tezą, że możliwa jest wiedza pewna nie tylko na temat geometrii, lecz także innych prawd wiecznych, np. prawdy o Dobru. Tezy tej bronił Platon. Jego argumentacja przedstawia się następująco:

„1. Znamy prawdy geometryczne, których nie poznaliśmy ani przez nauczenie się, ani przez doświadczenie.

2. Wiedza ta jest przykładem prawd niezmiennych i uniwersalnych, które zatem jesteśmy w stanie postrzegać i rozpoznawać.

3. Musi zatem istnieć świat absolutnej i niezmiennej prawdy, źródło i podstawa naszej wiedzy o Dobru." (Davis, Hersh i Marchisotto: 315).

Innymi słowy, sukces geometrii miał być gwarancją sukcesu filozofii w osiągnięciu wiedzy pewnej, o ile tylko zostanie w niej zastosowana metoda aksjomatyczna. ${ }^{8}$ Taki sam pogląd głosili również filozofowie racjonalistyczni: Kartezjusz, Spinoza i Leibniz. (Davis, Hersh i Marchisotto: 315). Dla pełności obrazu dodajmy jednak, że pogląd, jakoby aksjomaty geometrii były oczywiste same przez się, jest charakterystyczny raczej dla filozofii nowożytnej: „Błędnie ocenialibyśmy zmysł krytyczny Greków, gdybyśmy wyobrażali sobie, że nawet ,aksjomaty', które Pascal uważał za najbardziej oczywiste [...] nie były przedmiotem dyskusji." (Bourbaki 1980: 22). Ten sam autor stwierdza dalej, że reguły wnioskowania matematycznego musiały się wytworzyć „W wyniku doświadczeń i w ogniu krytyki.” (Bourbaki 1980: 23). Widać stąd, że mit Euklidesowy kształtował się stopniowo. Tym niemniej, istotnie, do XIX w. trwał niezagrożony. (Davis, Hersh i Marchisotto: 315). Na przełomie XIX i XX w. zaczęły następować zmiany w matematyce, które doprowadziły do jego erozji: odkryto funkcje o nietypowych, „kontrintuicyjnych” właściwościach (chodzi o funkcje ciągłe i zarazem nieróżniczkowalne), a przede wszystkim odkryto geometrie nieeuklidesowe, czyli odrzucające 5 postulat geometrii Euklidesa. ${ }^{9}$ Geometria euklidesowa okazała się być szczególnym przypadkiem geometrii, nie można więc było twierdzić, że jest po prostu opisem świata realnego. (Bourbaki 1980: 19-35).

Oczywiście, z tezy, że geometria, czy szerzej: matematyka, nie opisuje świata realnego, nie wynika, że zajmuje się bytami fikcyjnymi. Można wszak postulować świat bytów idealnych, lub twierdzić, że matematyka bada byty możliwe. Tym niemniej, przestało być oczywiste, że

$8 \quad$ Zauważmy dla porządku, że nie jest to bynajmniej wniosek pewny - można z powodzeniem uznawać twierdzenia geometrii za absolutnie pewne, kwestionując zarazem możliwość osiągnięcia przez filozofię takiej pewności. Trzeba by dodatkowo założyć, jak zdawał się czynić Platon, że istnieją prawdy poznawalne a priori, dotyczące zagadnień filozoficznych.

9 Postulat ten głosi, że suma kątów w trójkącie wynosi 180 st., co jest równoważne twierdzeniu, że proste równoległe nigdzie się nie przecinają. Krótkie i popularne omówienie problematyki geometrii nieeuklidesowej w: Davis - Hersh - Marchisotto 2001: 210-216. 
geometria Euklidesa opisuje świat realny, ${ }^{10}$ skoro jest tylko jedną z geometrii. Nie ma więc żadnej gwarancji, że teorie budowane na apriorycznych założeniach, nawet gdyby jawiły się jako oczywiste, pasują do świata realnego - wymaga to dopiero sprawdzenia. Tym samym nie można mieć zaufania do spekukacji filozoficznej. Euklides jest tu symbolem wiary, że abstrakcyjne rozumowania oparte o rzekomo oczywiste i niepodważalne założenia, pozwolą poznać świat realny. Nieuprzejme, przytaczane już uwagi Iana o tyłku Euklidesa i jego nosie, zdają się zawierać sugestię, że założenia mające stanowić niewzruszoną podstawę poznania, $\mathrm{w}$ istocie są ekstrapolacją partykularnych doświadczeń na ogół rzeczy: „Był przekonany, że to, co słuszne dla trójkąta wielkości jego nosa i dla koła wielkości jego tyłka, będzie słuszne dla wszystkich trójkątów i kół, niezależnie od tego, jak ogromnych, czy jak malutkich." (Themerson 2013: 229). ${ }^{11}$

Z dotychczasowych analiz wynika, że błąd Euklidesa - w ujęciu Iana - polegał na uznaniu ciągłości czasoprzestrzeni, co pociągnęło za sobą pogląd, że to, co niezmienne i wieczne, jest doskonalsze niż to, co zmienne i czasowe i że jest fundamentem bytowym dla rzeczy zmysłowych i konkretnych. Ponadto geometria Euklidesa stanowi wzorzec rozumowań apriorycznych i całkowicie pewnych, za pomocą których można poznać świat realny. Euklides jest więc tu symbolem filozoficznej tradycji Zachodu przyjmującej te założenia. ${ }^{12}$ Themerson tradycję tę odrzuca, a w każdym razie poddaje znaczącej korekcie. Przede wszystkim, wydaje się podważać pogląd, że to, co zmienne musi mieć fundament w tym, co niezmienne. Jego wizję świata wyraża wiersz:

„Gramatycznie - wydaje mi się, że w ogóle

nie jestem rzeczownikiem. Jestem czasownikiem.

Przez miliardy lat nie byłem.

Potem zacząłem się dziać.

Teraz się dzieję.

I wkrótce przestanę się dziać.

To są cechy czasownika, a nie rzeczownika...” (Themerson 1993:5)

Jak pisze Pruszyński: „Słowa te wskazują na pozorność istnienia rzeczowników. Wydają się one trwalsze, bo czynności nie są namacalne, tak jak przedmioty. A jednak trwanie rzeczowników ma charakter równie ulotny, jeśli spojrzeć na nie z odpowiedniego dystansu." (Pruszyński 2004: 137). Wypada jednak sądzić, że jest to tylko pewna propozycja widzenia rzeczywistości, bo jak dalej się okaże - Themerson podkreśla znaczenie badań empirycznych. Tym niemniej takie spojrzenie na świat współgra z wizją zawartą w rozprawie Iana.

Świat nie jest jednak doskonały, już choćby dlatego, że jest w nim okrucieństwo. Ian w rozmowie z Timem Chestertonem-Brownem, filozofem, wyjaśnia dlaczego nie może zostać biologiem: „gdyż biologia jest taka krwawa, taka brudna, taka brzydka, wszystko, co żyje, jest takie

10 Dodajmy, że zgodnie z ogólną teorią względności geometria Euklidesa właśnie nie opisuje świata realnego.

11 To oczywiście tylko niektóre inspiracje filozoficzne Themersona. Pominęliśmy zwłaszcza problematykę granicy i ciągłości, z którą wiąże się koncept geometrii zakładającą ziarnistość czasu i przestrzeni. Nie jest to bowiem istotne z punktu widzenia naszych celów badawczych.

12 Nie twierdzimy bynajmniej, że tradycja filozoficzna Zachodu to monolit, twierdzimy tylko, że wskazane założenia, różnie zresztą interpretowane i rozwijane, są w niej obecne. Gdy w dalszej partii tekstu będzie mowa o tej tradycji, w istocie będzie chodzić o tę jej część, którą Themerson poddaje krytyce. 
brzydkie." (Themerson 2013: 89). Na replikę Tima, jak piękne są ptaki wzbijające się w powietrze, odpowiada: „Tak, proszę pana. Ładnie jest na nich patrzeć. Ale pod skórą są brzydcy. Cała ta krew i wnętrzności, i gruczoły, i komórki, które zabijają, walczą, pożerają, rosną, umierają. Są brzydkie. Brzydkie etycznie.” (Themerson 2013: 89). Również sprawami ludzkimi wydaje się rządzić chaos, przejawiający się nie tylko w nieprzewidywalności losu, lecz także w nietypowych, najoględniej mówiąc, decyzjach moralnych. Weronika, żona Tima, popełnia cudzołóstwo z kapitanem Casanovą, nie po to jednak, by zdradzić męża, lecz by nauczyć się, jak uprawiać miłość z mężem, gdy ten stracił nogi. Z kolei, kapitan Casanova dopiero po zbliżeniu z Weroniką ma poczucie, że zdradził żonę, nieżyjącą, notabene, od dwunastu lat. Jak jednak stwierdza kapitan: „To nie my wymyśliliśmy ten świat, taki jaki jest.” (Themerson 2013:121). Zatem to świat odpowiada za ich czyn, nie oni. Przez całą powieść przewija się pretensja do świata. Nie jest to zaskakujące, jeśli zważyć, że, jak pisze Małgorzata Wosnitzka: „Wyznawany przez Themersona sceptycyzm i uprawiane różnorodne formy powiastek filozoficznych były w pewnym sensie odpowiedzią na okrucieństwa czasów okupacji." (Wosnitzka 2016:331). Badaczka pisze jednak, że Themerson rzadko poruszał wprost ten temat.

Odrzucenie poglądu, że możliwa jest wiedza aprioryczna na temat świata realnego, prowadzi do podkreślenia znaczenia badań empirycznych. W rozmowie z Timem Chestertonem-Brownem Ian stwierdza: „Błędem jest decydowanie tylko za pomocą myślenia, czy w momencie kiedy Achilles dogania żółwia, odległość między jego dużym palcem u nogi, a ogonem żółwia jest zerowa, czy też nieskończenie mniejsza niż jakakolwiek wyobrażalna mała odległość, ale nie zerowa, lub że odcinek czasu w momencie kiedy dogania żółwia ma długość zerową czy nie zerową." (Themerson 2013: 86). Rozwiązanie paradoksu Achillesa i żółwia zależy bowiem od rozpoznania struktury świata - właśnie w tym miejscu powieści pojawia się pierwszy wywód o geometrii stanowiącej alternatywę dla Euklidesa. I dalej: „takich rzeczy nie można odkryć drogą rozumowania, trzeba je naprawdę odkryć za pomocą odkrywania" (Themerson 2013: 88). Prymat empirii w stosunku do rozumowania prowadzi do wniosku, że prawdy faktyczne są ważniejsze od prawd koniecznych. Narzucają się one w sposób bezpośredni, natomiast prawdy konieczne zależne są ostatecznie od naszych konstrukcji intelektualnych: „To verité de fait, prawda błękitnych fal i czarnych pudli, i oderwanych nóg jest niezaprzeczalna, podczas gdy verité de la raison składa się z tautologii i paradoksów i nie może sprostać temu naszemu najlepszemu ze światów." (Themerson 2013: 80). Pogląd taki wyrażał zresztą Themerson także w innych tekstach: „Kiedy słowa mówią, że jakaś rzecz jest niemożliwa z powodu pewnej logicznej konieczności, a fakty, nawet te opisane przez wymyślony eksperyment, pokazują sposób, w jaki to coś może się pojawić, to wniosek musi być taki: że nasza bezbłędna logika opiera się na błędnym założeniu, założeniu któremu nie udało się odnieść do rzeczywistości świata." (Themerson 2002: 232).

Takie postawienie sprawy oznacza uznanie wyższości nauk empirycznych nad filozofią, w której większą rolę odgrywa czynnik aprioryczny i której teorii nie można testować przez eksperymenty. Zwłaszcza, że filozofia w praktyce jest uprawiana tak: „Bo czytasz mnóstwo książek, potem piszesz artykuł do czasopisma filozoficznego. Ale autorzy książek, które przeczytałeś, musieli, zanim je napisali, przeczytać inne książki. A ci, co napisali te inne książki, musieli przeczytać jeszcze inne, dawniejsze i tak dalej, aż dotrzemy do jakiegoś starożytnego jegomościa, który nie miał nic do przeczytania, kiedy pisał swoją książkę, to znaczy nic prócz 
Księgi Natury. Ciekawa jestem, dlaczego ty nie zwrócisz się wprost do Księgi Natury, po co ci tamci wszyscy pośrednicy?" (Themerson 2013:35-36). Filozofowanie polega często na odnoszeniu się do cudzych teorii czy też argumentów, po to, by wyrazić własne stanowisko. W rezultacie jednak filozof, zamiast obcować z rzeczywistością, obcuje z wytworami ludzkiego umysłu. ${ }^{13}$ Weronika zarzuca też swojemu mężowi: „A kiedy zadać ci najprostsze pytanie, wpadasz w popłoch." (Themerson 2013:36). Jako przykład podaje pytanie: dlaczego istnieje coś, a nie nic? Na co jej mąż odpowiada: „Och, to Heidegger.” (Themerson 2013: 36) - nie odnosi się więc do samego problemu, a tylko wskazuje na autora, który się nim zajmował. To skądinąd zrozumiałe: proste pytania wcale nie muszą mieć równie prostych odpowiedzi. Każda odpowiedź nasuwa kolejne pytania - o jej uzasadnienie, o sensowność samego pytania, o jej konsekwencje, o odpowiedzi konkurencyjne i tak z jednego, prostego pytania wyrasta cały zbiór problemów. Paradoksalnie, próby odczytania Księgi Natury powodują, że się od niej oddalamy. Nie inaczej jest w naukach przyrodniczych. Tim odnosząc się do słów żony, stwierdza: „Czy ona nie wie, że świat nie jest już taki sam jak w epoce Beniamina Franklina? Czy nie wie, że Księgę Natury porwały na strzępy miliony wyspecjalizowanych naukowców, którzy wygryzają sobie drogę przez jej stronice? I co? I tworzą teorie fizyczne, które pomagają wytwarzać różne urządzenia!' (Themerson 2013:41). Nie znaczy to, że Themerson opowiada się za sceptycyzmem; raczej wskazuje na ograniczenia naszego poznania.

Dokonana przez Themersona korekta założeń obecnych w tradycji filozoficznej Zachodu została więc wymuszona trudnościami, jakie pojawiły się w procesie poznania świata. Wydaje się jednak, że jest też drugi powód, dla którego dystansuje się od tradycji, symbolizowanej w jego powieści przez Euklidesa. Sądzimy, że tradycja ta jest dla Themersona źródłem fanatyzmu i okrucieństwa, a przynajmniej czynnikiem mogącym podsycać tkwiącą w człowieku skłonność do takich postaw i ją sankcjonować. Aprioryzm może przejawiać się nie tylko w poznawaniu świata, lecz także w jego urządzaniu zgodnie z jakimś rzekomo idealnym projektem. A to już rodzi groźne skutki praktyczne. Powieść zaczyna się od opisu wielkiego pisarza, Bernarda St. Austella: „Wiedział, że ta jego nienawiść ma swoje własne, niezależne od niego życie, że tkwi w nim cały czas, wciąż, że jest częścią jego anatomii [...].” (Themerson 2013: 9). Ujawniała się ona w jego pisarstwie. „I choć w tym, co pisał, nienawiści tej bezpośrednio widać nie było, to jednak z niej właśnie czerpał podnietę i energię do pracy.” (Themerson 2013: 9-10). Natomiast w życiu domowym nie ujawniała się wcale. Wszystko zmieniło się, gdy jego syn wyraził w jakiejś kwestii odmienne zdanie. Wówczas zaczął go nienawidzić. „Jego arystotelesowska logika nie miała szczelin. A więc każdy, kto się z nim nie zgadzał, był albo głupcem, albo odrzucał jego przesłanki. Głupców nie tolerował. A człowiek, który miał inne niż on przesłanki, to gorzej niż wróg, to Duchowy Cudzoziemiec. Jego syn nie jest głupcem. A mieć duchowego cudzoziemca we własnej rodzinie - nie, to przekraczało jego wytrzymałość. Czuł, że byłby zdolny go zamordować." (Themerson 2013: 16-17). W cytowanym fragmencie pojawia się odwołanie do Arystotelesa, który równie dobrze, jak Euklides, nadaje się na symbol filozoficznej tradycji Zachodu. Wydaje się więc, że jego imię pada tu nieprzypadkowo i jest symbolem absolutyzowania logiki resp. apriorycznych rozumowań - przypomnijmy, że stworzył on pierwszy

13 Nic tak nie oddaje tej sytuacji, jak ewolucja znaczeniowa terminu ,teoria'. W grece theoria oznacza ,ogląd', a zatem filozofowanie polega na kontemplacji. Obecnie ,teoria’ oznacza zbiór zdań powiązanych wynikaniem logicznym, lub strukturę logiczną mającą opisywać jakiś wycinek resp. aspekt rzeczywistości. 
rachunek logiczny, tj. sylogistykę. ${ }^{14}$ Dla St. Austella ważniejsze od więzów rodzinnych okazują się być przekonania, którym hołduje. Wkrótce zresztą umiera, zaś jego żona i kochanka nawiązują ze sobą romans. Zamieszkują razem, a wieczorami wychodzą tańczyć. Dlatego nazwano je Tańczącymi Paniami. Być może zasadne jest przypuszczenie, że budują w ten sposób alternatywę dla męskiego świata napędzanego przez konflikt. Przed szaleństwem ideologii, czy też projektów naprawy świata uchronić może tylko ciepło zwyczajnych, ludzkich relacji, nawet tak nietypowych, jak związek miłosny wdowy i kochanki jej męża. Ale wydaje się, że może chodzić o coś więcej. W omawianej powieści jedna z postaci powiada: „Czy nie sądzi pani, Madame, że te Siostry Żmije (odnosiło się to do Tańczących Pań) to Filles de la Terre, furie, erynie, które po sądzie nad Orestesem przestały nękać grzeszników i teraz jako eumenidy usiłują wymazać z pamięci wszystkie wspomnienia owych crimes terribles, za jakie musiały ich karać." (Themerson 2013: 128). Jest to nawiązanie do Orestei Ajschylosa. Erynie to, jak wiadomo, boginie zemsty ścigające zbrodniarzy. Po ustanowieniu sądu, który ma zastąpić zemstę rodową, i po wyroku uniewinniającym Orestesa, Erynie otrzymują miejsce kultu w Atenach. Odtąd mają się stać Eumenidami, opiekunkami miasta. (Ajschylos 2016: 214-236). Ich prawa nie zostają podeptane, zmienia się tylko sposób ich realizacji, a one same stają się częścią porządku polis. (Spaemann 2006: 273-274). Skoro więc Tańczące Panie to Erynie, które stały się Eumenidami, to symbolizują one odrzucenie zemsty, albo raczej jej przezwyciężenie, skoro (jednak!) zostały nazwane Eryniami. Być może ich taniec jest buntem przeciw złemu światu, a zarazem tworzy enklawę wolną od jego wpływów. W każdym razie wydaje się pewne, że Tańczące Panie realizują postawę przeciwstawną względem postawy St. Austella.

Gdy Themerson krytykuje projekty naprawy świata, ma na myśli nie tylko ideologie totalitarne, ale również chrześcijaństwo. Dame Wiktoria, w rozmowie ze swoją wnuczką, członkinią organizacji terrorystycznej, tak odpowiada na jej zarzut, że nie rozumie, co to jest Idea. „Jestem szczerze wdzięczna, że nic nie wiem o Ideach. Wdzięczna, że za młodu nie kształcono mnie, żebym wierzyła w Idee.” (Themerson 2013: 62). I dalej: „Zamiast tego uczono mnie języków i co wypada, a czego nie wypada robić." (Themerson 2013: 62). Dalej opowiada, że jej guwernantki i nauczycielki nigdy nie mówiły ,należy', bo gdyby to robiły, zaraz pojawiłoby się pytanie,dlaczego?', „a one miały w posiadaniu Mądrość, dzięki której wiedziały, że nie ma ostatecznej odpowiedzi na taką procesję dlaczego? dlaczego? dlaczego?, uczciwiej jest więc po prostu mówić ,tak się robi', ,tak się nie robi', żadnych pytań, kropka." (Themerson 2013: 63). Szukanie odpowiedzi na pytanie, dlaczego należy postępować w dany sposób, prowadzi do wymyślania idei, a one z kolei usprawiedliwiają mord na ludziach, którzy się z nimi nie zgadzają. Tak samo, zdaniem dame Wiktorii, postąpił Jezus, „chociaż On sam się najpierw poświęcił i w nas wszystkich wzbudził poczucie winy i za jego sprawą wciąż deklamujemy Milość. Miłość. Miłość; czy nie wiedział, ile nienawiści miłość powoduje w świecie?" (Themerson 2013: 64). Istotnie, omnis odium ex amore causatur. Zamiast więc wzywać do miłości, należało stwierdzić, że są rzeczy, które się robi i rzeczy, których się nie robi. Zamiast ideologii i doktryn moralnych Themerson proponuje „etykę dobrych manier” resp. „zwyczajną przyzwoitość. Nakazuje ona matkom, by nie zjadały swoich dzieci i zakazuje posługiwania się niegodziwymi środkami do realizcji najszczytniejszych

14 Nie trzeba chyba dodawać, że nie każdy, kto się przyznaje do Arystotelesa i do logiki, musi zajmować postawę taką, jak St. Austell. Warto za to zauważyć, że Arystoteles z powodzeniem mógłby symbolizować trzymanie się empirii, zwłaszcza w etyce. 
choćby celów. Reguły przyzwoitości służą przetrwaniu; nie gwarantują uniknięcia tragedii, ale zapobiegają niechybnym nieszczęściom, jakie przynoszą samozwańczy zbawcy. Zdaniem Pruszyńskiego etyka dobrych manier oznacza dominację środków nad celami. (Pruszyński 2004: 193). Pisze też: „Wydaje się zatem, że Themerson chciał znaleźć kamień filozoficzny etyki, zwany prawem naturalnym, stawiając na pierwszym miejscu ,dobre maniery', czyli wiedzę (w dużej mierze intuicyjną) o tym, jak należy w danej sytuacji postąpić. Jednocześnie oparł się jednak na tradycji kulturowej." (Pruszyński 2004: 212). Etyka dobrych manier byłaby więc z jednej strony odrzuceniem konsekwencjalizmu w teorii moralności: istnieją acta intrinsice mala, czyny wewnętrznie złe, których nie wolno dokonywać nigdy. Z drugiej strony nie opiera się na żadnej teorii moralnej, ani jej nie wymaga. Themerson wyraża zmęczenie projektami naprawy świata, próbuje więc wskazać jakąś moralność, jakiś modus vivendi ponad światopoglądowymi, aksjologicznymi i politycznymi podziałami. Wskazuje tedy na proste impulsy moralne, które zna każdy. Wydaje się, że tak pojmowana etyka musi zakładać, że wszyscy mają te same impulsy moralne resp. uczucia i wszyscy tak samo je hierarchizują. Nie jest naszym zadaniem ocena, czy jest to założenie trafne.

Konkludując zatem, Euklides okazał się osłem, bo nauczył nas obracać się w kręgu abstrakcji, które w pewnych okolicznościach mogą okazać się groźne. Nauczył nas też apriorycznych rozumowań, które mogą nas sprowadzić na manowce, gdy będziemy je stawiać ponad doświadczenie. Z takiej perspektywy filozoficzne żarty Themersona nie są tylko niewinną zabawą, lecz, być może, stanowią próbę odebrania powagi tak niebezpiecznemu zajęciu. Jeśli filozofia jest potrzebna człowiekowi, to nie może rościć sobie pretensji do odkrywania prawd ostatecznych, nie tylko z powodu ograniczeń poznawczych, lecz także ze względu na niebezpieństwa moralne związane $\mathrm{z}$ takim roszczeniem.

\section{WHY WAS EUCLID A DONKEY? REMARKS ON STEFAN THEMERSON'S THE MYSTERY OF THE SARDINE}

SUMMARY The article is an attempt at a philosophical commentary on Stefan Themerson's novel The mystery of the sardine (polish title: Euklides byt osłem). First, some of the philosophical inspirations of the novel are presented, and then Themerson's critique of the tendencies towards apriorism in Western philosophy, symbolized by Euclid.

\section{BIBLIOGRAFIA}

I Ajschylos, 2016, Tragedie. T. 2: Oresteja: Agamemnon, Ofiarnice, Boginie łaskawe, przeł., wstępami i przypisami opatrzył R. R. Chodkowski, Lublin.

I Bourbaki N., 1980, Elementy historii matematyki, tł. S. Dobrzycki, Warszawa.

I Davis P. J. - Hersh R. - Marchisotto E. A., 2001, Świat matematyki, przekł. R. Duda, Warszawa.

I Legutko R., 2020, Filozofia presokratyków. Od Talesa do Demokryta, Kraków. 
I Lovejoy A. O., 2009, Wielki łańcuch bytu. Studium historii pewnej idei. Z dodaniem tekstów „Historiografia idei”, „Obecne stanowiska i przeszła historia” oraz „Refleksje o historii idei”, przeł.

A. Przybysławski, Gdańsk.

I Platon, 1986, Timajos. Kritias, albo Atlantyk, przeł. P. Siwek, Warszawa.

I Prószyński A, 2004, Dobre maniery Stefana Themersona, Gdańsk.

I Spaemann R., 2006, Nienawiść Sarastra. Granice. O etycznym wymiarze dziatania, Warszawa.

I Themerson S., 2002, O filozoficznym znaczeniu tego, co niefilozoficzne, „Kresy”, $2002 \mathrm{nr} 1$, s. 227-233.

I Themerson S., 2013, Euklides był osłem, przeł. I. Szymańska, Warszawa.

I Themerson S., 1993, Jestem czasownikiem, czyli zobaczyć świat inaczej, wybór i oprac. M. Grala, Płock.

I Wosnitzka M., 2016, Komplikowanie świata. Nauka i sztuka Stefana Themersona. Żydzi wschodniej Polski. Ser 4. Uczeni żydowscy, Białystok, s. 331-342. 